\title{
Ectoparasites infecting Mugil curema \\ (Mugiliformes: Mugilidae) in Amapá state estuary, in the northern Brazilian coast region
}

Joilson Rodrigues dos Santos

Faculdade de Mapá

Pedro Hugo Esteves-Silva

Universidade Federal do Pará: Universidade Federal do Para

Carlos Eduardo Costa-Campos

Universidade Federal do Amapá: Universidade Federal do Amapa

Marcos Tavares-Dias ( $\square$ marcos.tavares@embrapa.br)

Brazilian Corporation of Agricultural Research (Embrapa) https://orcid.org/0000-0002-8376-1846

\section{Research Article}

Keywords: Amazon, crustaceans, fish, infection, parasites

Posted Date: April 22nd, 2021

DOl: https://doi.org/10.21203/rs.3.rs-415698/v1

License: (c) (i) This work is licensed under a Creative Commons Attribution 4.0 International License.

Read Full License 


\section{Abstract}

In fish, one of the most important interactions is that occur between parasite species and environment. Wild fish interactions with parasites of different taxa can result in diseases for fish and consequently damages to the fishing industry. This study investigated the ectoparasite fauna in Mugil curema in Amapá state estuary, in Brazilian coast region. The parasite prevalence was $51.4 \%$, and a total of 282 parasites were collected among Ligophorus brasiliensis (Dactylogyridae), Excorallana longicornis (Corallanidae), larvae of Gnathia sp. (Gnathiidae) and Ergasilus atafonensis (Ergasilidae), but the dominance was of $L$. brasiliensis. The parasites presented highly aggregated dispersion, except for Gnathia sp. that had a random dispersion. There was a predominance of hosts parasitized by zero and one species. The relative condition factor did not differ between parasitized and non-parasitized fish. The body size of hosts did not influence the parasite abundance. The community of ectoparasites consisted of low species richness with low infection levels. This is the first study on parasites of fish from the coast of the State of Amapá and is the first report of Gnathia sp. for M. curema.

\section{Introduction}

Fish have a great importance for human populations, as well as for nutrition of animals with zootechnical interest. Fishing is one of the fundamental and effective ways to quickly find food in nature, from the earliest times, in order to meet the existential needs, which is why it became one important branch of economics (Golzio et al. 2017; Nedić et al. 2018). Mugil curema (Valenciennes, 1836), named white mullet, a pelagic fish of the family Mugilidae in Americas that is distributed from Cape Cod (USA) to Brazil, has a great importance for fishing. It has also been reported in the Senegal River outlet southwards to Namibia, in Africa (Ibáñez-Agurre et al. 2006; Froese \& Pauly 2021). This white mullet species is an important commercial fishing resource because of its fatty meat of good quality. Juveniles of M. curema enter the lacustrine-estuarine systems, where they grow to reach the adult stage, and then migrate in shoals to the coastal pelagic zone to spawn. This fish feeds on microscopic or filamentous algae and planktonic organisms (Cavalcanti et al. 2011; Moutinho \& Alves 2014; Ruiz-Ramírez et al. 2017). Due to the development of aquaculture programs for M. curema, ecological studies on parasites have increased in wild populations of this fish.

Understanding how the parasites are distributed and their interactions with host fish populations and environment are among the basic aims of parasitology of fish (Cavalcanti 2011; Golzio et al. 2017; Nedić et al. 2018; Neves \& Tavares-Dias 2019). In this context, parasite-host-environment systems constitute excellent study models to explore these essential aspects of parasitic ecology in wild fish populations. Thus, for wild $M$. curema from the Brazilian coast it has been reported infections by crustaceans Caligidae gen. sp., Caligus sp., Acanthocolax sp.; Caligus bonito (Wilson, 1905), Caligus minimus (Otto, 1821), Caligus praetextus (Bere, 1936), Cymothoa spinipalpa (Thatcher, Araújo, Lima \& Chellappa, 2007), Ergasilus sp.; Ergasilus versicolor(Wilson, 1911), Ergasilus lizae (Kroyer, 1863), Ergasilus atafonensis (Amado \& Rocha, 1995), Ergasilus caraguatatubensis (Amado \& Rocha, 1995), Ergasilus bahiensis (Amado \& Rocha, 1995), Bomolochus nitidus (Wilson, 1911) and Excorallana longicornis (Lemos de 
Castro, 1960), monogeneans Ligophorus mugilinus (Hargis, 1955), Ligophorus brasiliensis Abdallah, (Azevedo \& Luque 2009), Ligophorus spp. and Metamicrocotyla macracantha (Alexander, 1954), and digenean Ascocotyle sp. metacercariae (Amado \& Rocha, 1995; Fonsêca et al. 2000; Cavalcanti et al. 2005; Cavalcanti et al. 2011; Namba et al. 2012; Moutinho \& Alves 2014; Golzio et al. 2017; Esteves-Silva et al. 2020; Falkenberg et al. 2021). However, parasites of M. curema from the Amapá State estuary have not been addressed.

In migratory fish populations, migration potentially affects the distribution and abundance of parasites in ecosystems (Salgado-Maldonado et al. 2019); thus, they have a wide ecological interaction in aquatic ecosystems of its geographic distribution. One of these most important interactions is with different taxa of parasite species, which can result in diseases. Such diseases can be highly damaging for fish and consequently to the local economics (Cavalcanti et al. 2011; Golzio et al. 2017; Nedić et al. 2018; Neves \& Tavares-Dias 2019). Parasitic diseases usually occur when there is an imbalance between environment, host and parasite community in fish population (Pedro et al. 2016; Mentz et al. 2016). Ectoparasites can have the potential to exert effects on the behavior, biology, development, health and appearance of the host fish (Fonsêca et al. 2000; Cavalcanti et al. 2011; Nedić et al. 2018; Neves \& Tavares-Dias 20199). Providing that the associations between ectoparasites and impacts have been established, this could offer predictive tools to assess the magnitude of impacts on fish populations (Fajer-Ávila et al. 2006; Golzio et al. 2017; Neves \& Tavares-Dias 2019). Thus, it is important to know the parasitic fauna of wild fish populations and to consider the effects of parasites on host health, because these may help to understand impacts on fish populations and effects of aquatic ecosystems on parasite communities (Mentz et al. 2016; Neves \& Tavares-Dias, 2019). The aim of this study was to investigate the ectoparasite fauna in $M$. curema from the Amapá state estuary, in the Brazilian coast.

\section{Material And Methods}

\section{Fish collection and study area}

Thirty-five specimens of M. curema were collected bimonthly, between June 2017 and March 2018 in the Maracá-Jipióca Ecological Reserve ( $\left.1^{\circ} 50^{\prime \prime} 00^{\prime \prime} \mathrm{N} ; 2^{\circ} 12^{\prime \prime} 00^{\prime \prime} ; 50^{\circ} 33^{\prime \prime} 00^{\prime \prime} \mathrm{W}\right)$. Fishes were caught using gill nets with different mesh sizes (30, 40 and $50 \mathrm{~mm}$ ), which remained about 4 hours/day in the water. Later, each fish was placed in a plastic bag and stored in thermal boxes containing ice, transported to the base of the Chico Mendes Institute for Biodiversity Conservation (ICMbio) 2018 in the Maracá-Jipióca Ecological Reserve and identified (Nelson et al. 2016).

The Maracá-Jipióca Ecological Reserve is located along the Atlantic zone of the State of Amapá. It has $750 \mathrm{~km}$ and extends between the mouth of the Oiapoque and Araguari rivers, being separated from the coast by the channels of Caraporis or Varadorouro de Maracá. It is made up of three islands: Maracá Norte, Maracá Sul and Jipióca that are located on the river-marine floodplain, between the municipalities of Amapá and Oiapoque (Monteiro 2009). 
This study was developed in accordance with the principles adopted by the Brazilian College of Animal Experimentation (COBEA), and with the authorization from ICMBio (\#59031-1) and authorization from Ethics Committee on Animal Use of Embrapa Amapá (Protocol № 014/2018).

\section{Collection and analysis of parasites}

At the site, the body surface, operculum and anus of fish were examined for the presence of ectoparasitic crustaceans. Fish were weighed $(\mathrm{g})$ and measured in total length $(\mathrm{cm})$, and necropsied for parasitological analysis. Gills were removed and fixed in $5 \%$ formalin for collection of ectoparasites and examined under stereomicroscope and microscope. The collection, fixation, preservation, counting and staining of the parasites for identification followed Eiras et al. (2006).

The ecological terms used for the parasite infracommunities followed Bush et al. (1997). We used the dominance frequency (percentage of the infracommunities in which a parasite species is numerically dominant) (Rohde et al. 1995; Magurran 2004). In order to detect the distribution pattern of the parasite infracommunities (Rózsa et al. 2000), the index of dispersion (ID) and the Poulin discrepancy index (D) were calculated using the Quantitative Parasitology 3.0 software for species with prevalence $>10 \%$. The ID significance for each infracommunity was tested by $d$-statistics (Ludwig \& Reynolds 1988). The length and body weight of fish were used to compare the relative condition factor $(\mathrm{Kn})$ of parasitized and nonparasitized fish (Le Cren 1951) using the $t$-test. The correlation between the parasite abundance with length and weight of hosts was estimated using the Spearman correlation coefficient (Zar 2010).

\section{Results}

In M. curema, ectoparasite prevalence was $51.4 \%$, and a total of 282 parasites were collected among Ligophorus brasiliensis Abdallah, Azevedo \& Luque, 2009 (Monogenea: Dactylogyridae), Excorallana longicornis Lemos de Castro, 1960 (Isopoda: Corallanidae), larvae of Gnathia Leach, 1814 (Isopoda: Gnathiidae) and juveniles of $E$. atafonensis (Copepoda: Ergasilidae), but the dominance was of $L$. brasiliensis (Table 1). 
Table 1

Species de ectoparasites in Mugil curema from the Amapá State estuary, northern Brazil.

$\begin{array}{lllllll}\text { Species of parasites } & P(\%) & \text { MI } & \text { MA } & \text { TPN } & \text { FD (\%) } & \text { SI }\end{array}$

\section{Monogenea}

$\begin{array}{lllllll}\text { Ligophorus brasiliensis } & 25.7 & 27.7 & 7.1 & 249 & 88.3 & \text { Brânquias }\end{array}$

\section{Crustacea}

\begin{tabular}{lllllll} 
Excorallana longicornis & 2.9 & 3.0 & 0.09 & 3 & 1.1 & Tegumento \\
\hline Ergasilus atafonensis & 17.1 & 1.8 & 0.3 & 11 & 3.9 & Brânquias \\
Gnathia sp. & 28.6 & 1.9 & 0.5 & 19 & 6.7 & Brânquias
\end{tabular}

P: Prevalence, MI: Mean intensity, MA: Mean abundance, FD: Frequency of dominance, TNP: Total number of parasites, SI: Site of infection.

Parasites presented a higly agreggated dispersion, except for Gnathia sp. that had a random dispersion pattern (Table 2). There was a predominance of hosts infected by zero and one species (Fig. 1).

Table 2

Dispersion index (ID), $d$-statistics and discrepancy index (D) for the ectoparasites infracommunities in Mugil curema from the Amapá State estuary, northern Brazil.

\begin{tabular}{|lllll|}
\hline Species of parasites & ID & $\boldsymbol{d}$ & D & Dispersion type \\
\hline Ligophorus brasiliensis & 2.603 & 4.998 & 0.806 & Aggregated \\
\hline Gnathia sp. & 1.412 & 1.492 & 0.756 & Random \\
\hline Ergasilus atafonensis & 1.829 & 2.846 & 0.838 & Aggregated \\
\hline
\end{tabular}

The relative condition factor $(K n)$ did not differ $(t=0.56 ; p=0.58)$ between parasitized $(K n=1.00 \pm 0.001)$ and non-parasitized hosts $(K n=0.99 \pm 0.04)$. No significant correlation was found between parasite abundance with the length and weight of M. curema (Table 3).

Table 3

Spearman correlation coefficient ( $r s$ ) of body parameters with the abundance of parasites in Mugil curema from the State of Amapá estuary (Brazil).

\begin{tabular}{|lllll|}
\hline Parameters & Length & \multicolumn{3}{l|}{ Weight } \\
\hline Parasite species & rs & $\mathrm{p}$ & rs & $\mathrm{p}$ \\
\hline Ligophorus brasiliensis & -0.06 & 0.74 & $0.08-$ & 0.66 \\
\hline Gnathia sp. & 0.14 & 0.42 & -0.02 & 0.92 \\
\hline Ergasilus atafonensis & 0.03 & 0.85 & 0.14 & 0.41 \\
\hline
\end{tabular}




\section{Discussion}

Parasite communities can be described quantitatively using several descriptors (e.g. abundance, intensity, richness, prevalence and diversity), which provide information on the structure of the parasitic community at different levels. Once the diversity and infection levels of parasites can be influenced by abiotic and biotic factors (Pedro et al. 2016; Santos et al. 2017; Neves \& Tavares-Dias 2019), studies on species composition of parasites are required to understand the role of the parasite community in ecosystems (Mentz et al. 2016; Pedro et al. 2016; Neves \& Tavares-Dias 2019). The ectoparasite community on $M$. curema was low, consisting of only one species of Monogenea and three species of Crustacea. Similar composition of the ectoparasite community was reported for M. curema from Puerto Rico, which was infected by two species of Monogenea and three species of Crustacea (Garcia \& Williams 1985). However, the ectoparasite community in M. curema from the estuary of the State of Paraiba (Brazil) was composed of one species of Monogenea and six species of Crustacea (Golzio et al. 2017). In addition, the parasitic prevalence (51.4\%) in M. curema from the coast of the State of Amapá was lower than reported for this same host species (94.6\%) from the coast of the State of Rio Grande do Norte (Brazil), which was infected only by crustaceans $E$. versicolor and E. lizae (Cavalcanti et al. 2005).

In M. curema, L. brasiliensis and E. atafonensis presented an aggregated dispersion pattern, while larvae of Gnathia sp. had a random dispersion. Host fish populations represents a collection of patches of resources among which the parasites are heterogeneously distributed. In general, parasite infracommunities are distributed in an aggregated manner between individual hosts, regardless of whether they are from poor or rich communities. This means that most host fish have a few parasites, while most parasites are concentrated in a few hosts. This aggregation allows the coexistence of species that would otherwise be excluded; hence, more parasite species can coexist in the same host population (Salgado-Maldonado et al. 2019). However, it has also been reported random disperion of parasites in fish populations (Fajer-Ávila et al. 2006; Pedro et al. 2016). The random distribution has been atributed to demographic randomness mechanisms. Specifically parasites are associated with a certain probability that an individual will die or a new infection will occur in a given time frame and with environmental randomness, which involves situations in which processes such as birth, death and immigration and emigration rates controll the parasite population growth and are not constant for a given species, but depend on environmental factors (Von Zuben 1997; Pedro et al. 2016).

The body condition of fish may be expressed by the weight-length relationship and constitutes the condition factor of the individual and population. This body parameter is a quantitative indicator of welfare and body condition of a fish population, reflecting recent environmental and nutritional conditions, or even the effect of parasitism (Guidelli et al. 2009; Vasconcelos \& Tavares-Dias 2016). Another consequence of parasitic infection in fish is body weight reduction, frequently associated with lipid decrease and muscle water content increase (Mentz et al. 2016). Fish size may influence the parasite load, since larger fish would present major infections due to longer exposure to the environment and larger contact with the ectoparasite species (Santos et al. 2017). However, in M. curema of the present study, the relative condition factor was not affected by the parasite load, as well as size (length 
and weight) of the hosts. The reason might be because the infection levels were low and this mullet species is resistant to stressors, like parasites, and thus showed no clinical signs of diseases. In constrast, Santos et al. (2017) reported an increase in abundance of E. versicolor in Mugil gaimardianus (Desmarest, 1831) from the estuary of the State of Pará (Brazil) according to the size of hosts.

Species of Ligophorus (Euzet and Suriano, 1977) are monogeneans highly specific to mullet species, because such ectoparasites and these Mugilidae have a long coevolutionary process (Golzio et al. 2017; Pahor-Filho et al. 2019). However, these parasites can cause damages to gills of mullets, such as severe hyperplasia and necrosis of the respiratory epithelium (Pahor-Filho et al. 2019) depending on infection levels. Mugil curema of the current study was infected by L. brasiliensis, a monogenean species originally described in Mugil liza Valenciennes, 1836 from the Guandu River, in the State of Rio de Janeiro, Brazil (Abdallah 2009). In addition, the infection levels by L. brasiliensis were higher than that reported for this same host from the estuary of the State of Paraiba, which was infected by Ligophorus mugilinus (Hargis, 1955) (Golzio et al. 2017). Falkenberg et al. (2021) reported first time the record of $L$. brasiliensis for $M$. curema. Therefore, this is the second record of L. brasiliensis for M. curema.

Fish generally interact closely with the substratum in estuarine environments. Thus, fish ectoparasites are considered endemic components of the substratum of these environments and can reflect habitat conditions, which include their interactions with benthic and planktonic organisms (Fajer-Ávila et al. 2006). Parasitic crustaceans have varied life cycle and history. Williams Jr \& Bunkley-Williams (2019) do not consider Corallanidae isopods as true parasites, because so little is known about their associations with host fish. Nevertheless, some species of Corallanidae are known by feeding on fish blood. We found E. longicornis infecting M. curema at a low infection level, similar finding was reported by Esteves-Silva et al. (2020), for this same host from Amapá coast (Brazil). Approximately 226 species of Gnathia in 12 genera and a single family are known around the world and although occurring at all latitudes they are more diverse and abundant in the tropics. The life cycle of Gnathiidae in fish is simple. The first juvenile stage occurs in fish, and the parasite that leaves the female finds a host, gorge and swell up with blood, and become the second stage (praniza larvae). The praniza larvae eventually drops off the host and finds a secluded place on the bottom to develop into the next phase, the zuphea, which swims up and finds a host to repeat this cycle (Williams Jr \& Bunkley-Williams 2019). Mugil curema was infected by Gnathia sp. at a low infection level. Ergasilidae species are found mostly in freshwater ecosystems and sometimes in estuarine and shallow coastal water ecosystems (Boxshall \& Defaye 2008; Williams Jr \& Bunkley-Williams 2019). They present a simple life cycle with two phases: naupliar and copepodid (Williams Jr \& Bunkley-Williams 2019). Although, in M. curema it was found E. longicornis, Gnathia sp., E. atafonensis and $E$. longicornis, this latter parasite species had the lowest infection level. This was the first record Gnathia sp., and second record of E. longicornis for M. curema.

\section{Conclusions}

This is the first study on the ectoparasites of M. curema from the estuary of the State of Amapá, showing new geographical records of parasites for this host collected in the northern Brazilian region. Furthermore, 
the community of ectoparasites was composed of one species of Monogenea and three Crustacea, which were ectoparasites with low species richness, low prevalence, low intensity and abundance. Lastly, this is an important contribution to the knowledge of the regional parasite diversity, and serves as a basis for future studies.

\section{Declarations}

\section{Acknowledgments}

The authors also thank the National Council for Scientific and Technological Development (CNPq, Brazil) for the productivity research fellowship awarded to Tavares-Dias, M (Grant 303013/2015-0).

\section{Author contributions}

All authors have participated in conception and design, or analysis and interpretation of the data; drafting the article or revising it critically for important intellectual content; and approval of the final version.

\section{Compliance with ethical standards}

Conflict of interest Authors declare that there is no conflict of interest regarding the publication of this paper.

\section{References}

Abdallah VD, Azevedo RK, Luque JL (2009) Four New Species of Ligophorus (Monogenea: Dactylogyridae) parasitic on Mugil liza (Actinopterygii: Mugilidae) from Guandu River, Southeastern Brazil. J Parasitol 95(4): 855-864.

Amado MAPM, Rocha CE (1995) Três novas espécies de copépodos parasitas do gênero Ergasilus (Poecilostomatoida, Ergasilidae) coletadas em filamentos branquiais de peixes mugilídeos do Brasil. Nauplius 3: 33-48.

Boxshall GA, Defaye D (2008) Global diversity of copepods (Crustacea: Copepoda) in freshwater. Hydrobiologia 595: 195-207. doi:10.1007/s10750-007-9014-4

Bush AO, Lafferty KD, Lotz JM, Shostak W (1997) Parasitology meets ecology on its own terms: Margolis et al. Revisited. J Parasitol 83(4): 575-583. doi: 10.2307/3284227.

Cavalcanti ETS, Pavanelli GC, Chellappa S, Takemoto RM (2005) Ocorrência de Ergasilus versicolore E. lizae (Copepoda:Ergasilidae) na tainha, Mugil curema (Osteichthyes: Mugilidae) em Ponta Negra, Natal, Rio Grande do Norte. Arq Ciên Mar 38: 131-134.

Cavalcanti ETS, Takemoto RM, Alves LC, Chellappa S, Pavanelli GC (2011) Ectoparasitic crustaceans on mullet, Mugil curema (Osteichthyes: Mugilidae) in the coastal waters of Rio Grande do Norte State, Brazil. 
Acta Sci Biol Sci 33(3): 357-362. doi: 10.4025/ actascibiolsci.v33i3.6796

Eiras JC, Takemoto RM, Pavanelli GC (2006) Métodos de estudo e técnicas laboratoriais em parasitologia de peixes. Eduem: Maringá, PR.

Esteves-Silva PH, Oliveira MSO, Gentil-Vasconcelos HC, Costa-Campos CE, Tavares-Dias M (2020) New records of hosts for Excorallana longicornis and Nerocila acuminata (Crustacea: Isopoda) in brackish fish from the coast of the State of Amapá (Brazil), with an update on the geographic distribution of Nerocila acuminata. J Parasit Dis 44(2):420-428. https://doi.org/ 10.1007/ s12639-020-01192-x

Fajer-Ávila EJ, García-Vásquez A, Plascencia-González H, Ríos-Sicairos J, García-de La Parra, LM, Betancourt-Lozano M (2006) Copepods and larvae of nematodes parasiting the white mullet Mugil curema (Valenciennes, 1836): indicators of anthropogenic impacts in tropical coastal lagoons? Environ Monit Assess 122: 221-237. doi: 10.1007/s10661-005-9177-2

Falkenberg JM, Lacerda, ACF, Vieira GHC (2021) Co-occurrence and niche overlap among gill parasites of the white mullet (Mugil curema Valenciennes, 1836) (Osteichthyes: Mugilidae) from the western Atlantic, Brazil. Parasitol Res 120: 849-859. https://doi.org/10.1007/ s00436-020-07015-5

Froese, R., \& Pauly, D. (2021). Editors. World wide web electronic publication. Retrieved fromwww.fishbase.org.

Fonsêca FTB, Paranaguá MN, Amado MAM (2000) Copepoda parasitas de peixes Mugilidae em cultivo estuarino - Itamaracá - Pernambuco - Brasil. Trab Oceanog Univ Federal Pernambuco 28(2): 157-172.

Garcia JR, Williams EH (1985) Temporal dynamics of metazoan parasite infections in the white mullet Mugil curema Valenciennes from Joyuda lagoon, Puerto Rico. Caribb J Sci 21(1-2): 39-53.

Golzio JESA, Falkenberg JM, Praxedes RCG, Coutinho AS, Laurindo MK, Pessanha A, Madi RR, Patrício J, Vendel AL, Souza GTR, Melo CM, Lacerda ACF (2017) Gill parasites of fish from two estuaries in northeastern Brazil: new hosts and geographical records. An Acad Brasil Ciên 89(3): 2281-2291. http://dx.doi.org/10.1590/0001-3765 201720160883.

Ibáñez-Agurre AL, Cabral-Solís E, Gallardo-Cabello M, Espino-Barr E (2006) Comparative morphometrics of two populations of Mugil curema (Piesces: Mugilidae) on the Atlantic and Mexican Pacific coasts. Scientia Marina 70(1): 139-145.

Le Cren ED (1951) The length-weight relationship and seasonal cycle in gonadal weight and condition in the perch (Perca fluviatilis). J Anim Ecol 20(2): 201-219.

Ludwig JA, Reynolds JF (1988) Statistical ecology: a primer on methods and computing. New York, NY: Wiley-Interscience Pub.

Magurran AE (2004) Measuring biological diversity. Oxford, UK: Blackwell Science. 
Namba TK, Madi RR, Ueta, MT (2012) Ascocotyle sp. metacercariae (Digenea: Heterophyidae) in tissues of mullets Mugil liza and Mugil curema (Osteichthyes: Mugilidae) collected in the fish trade of the Iguape city, Sao Paulo, Brazil. Neotrop Helminthol 6 (2): 271-275.

Mentz MB, Lanner M, Fagundes N, Sauter IP, Marques LS (2016) Ectoparasites on Mugil liza (Osteichthyes: Mugilidae) from the Tramandai-Armazém lagoon system, Southern Brazil. Panamjas 11(2): 130-134.

Moutinho FO, Alves DR (2014) Metazoan parasites of Mugil curema (Osteichthyes: Mugilidae) from the coastal Rio de Janeiro. Cadernos UniFOA 24: 67-75.

Nedić Z, Skenderović I, Adrović A (2018) Study of some ectoparasites of fishes from the Sava River as part of water management in Bosnia and Herzegovina. Tem Journal 7(2): 391-397. doi: 10.18421/TEM72-21 May 2018

Nelson JS, Grande TC, Wilson MVH (2016). Fishes of the world. $5^{\text {th }}$ ed. New Jersey: John Wiley \& Sons, Inc.

Neves LR, Tavares-Dias M (2019) Low levels of crustacean parasite infestation in fish species from the Matapi River in the state of Amapá, Brazil. Braz J Vet Parasitol 28(3): 493-498.doi:

https://doi.org/10.1590/S1984-29612019006

Pahor-Filho E, Klosterhoff MC, Marchiori NC, Vianna RT, Pereira-Júnior J (2019) Histological changes caused by Ligophorus uruguayense (Monogenoidea) in reared mullet Mugil liza. In Aguilera JG, Zuffo AM (Orgs). Ciências agrárias: campo promissor em pesquisa 3 (p. 76-84). Ponta Grossa (PR): Atena Editora.

Pedro NHO, Pellegrini LS, Azevedo RK, Abdallah VD (2016) Biodiversity of metazoan parasites in Acestrorhynchus lacustres (Lütken, 1875) (Characiformes: Acestrorhynchidae) from the Batalha River, São Paulo State, Brazil. Panamjas 11(4): 336-344.

Rohde K, Hayward C, Heap M (1995) Aspects of the ecology of metazoan ectoparasites of marine fishes. Inter J Parasitol 25(8): 945-970. doi: 10.1016/ 0020-7519(95)00015-T

Rózsa L, Reiczigel J, Majoros G (2000) Quantifying parasites in samples of hosts. J Parasitol 86(2): 228232. doi: 10.1645/0022-3395(2000)086[0228: QPISOH]2.0.CO;2

Ruiz-Ramírez S, Molina-Arenas EG, Lucano-Ramírez G, Aguilar-Betancourt C, Flores-Ortega JR, KosonoyAceves D, González-Sansón G (2017) Aspectos reproductivos de la lisa Mugil curema (Mugiliformes: Mugilidae) en la laguna costera de Barra de Navidad, Jalisco, México. Latin Amer J Aquatic Res 45(2): 443-456.doi: 10.3856/vol45-issue2-fulltext-19

Salgado-Maldonado G, Mendoza-Franco EF, Caspeta-Mandujano JM, Ramírez-Martínez C (2019) Aggregation and negative interactions in low-diversity and unsaturated monogenean (Platyhelminthes) 
communities in Astyanax aeneus (Teleostei) populations in a Neotropical river of Mexico. Inter J Parasitol: Parasites and Wildlife 8: 203-215. https://doi.org/ 10.1016/j.ijppaw.2019.02.005

Santos AFL, Diniz DG, Takemoto RM, França CCS, Fujimoto RY (2017) Occurrence of Ergasilus versicolor (Copepoda: Ergasilidae) in Mugil gaimardianus (Osteichthyes: Perciformes) from the estuarine area of Bragança, Pará, Brazil. Rev Biol 17(2): 8-11. doi: 10.7594/revbio.17.02.02

Vasconcelos HCG, Tavares-Dias M (2016). Host-parasite interaction between crustaceans of six fish species from the Brazilian Amazon. Acta Sci Biol Sci 38(1): 113-123.

Von Zuben CJ (1997) Implicações da agregação espacial de parasitas para dinâmica populacional na interação hospedeiro parasita. Rev Saúde Públ 31(5): 523-530.

Williams EH, Bunkley-Williams L (2019) Life cycle and life history strategies of parasitic Crustacea. In: Smit N, Bruce N, Hadfield K. (Eds.). Parasitic Crustacea (p. 179-266). Zoological Monographs, vol 3. Springer Nature: Switzerland.

Zar J H (2010). Biostatistical analysis (5 ${ }^{\text {th }}$ ed.). Englewood Cliffs, NJ: Prentice Hall.

\section{Figures}




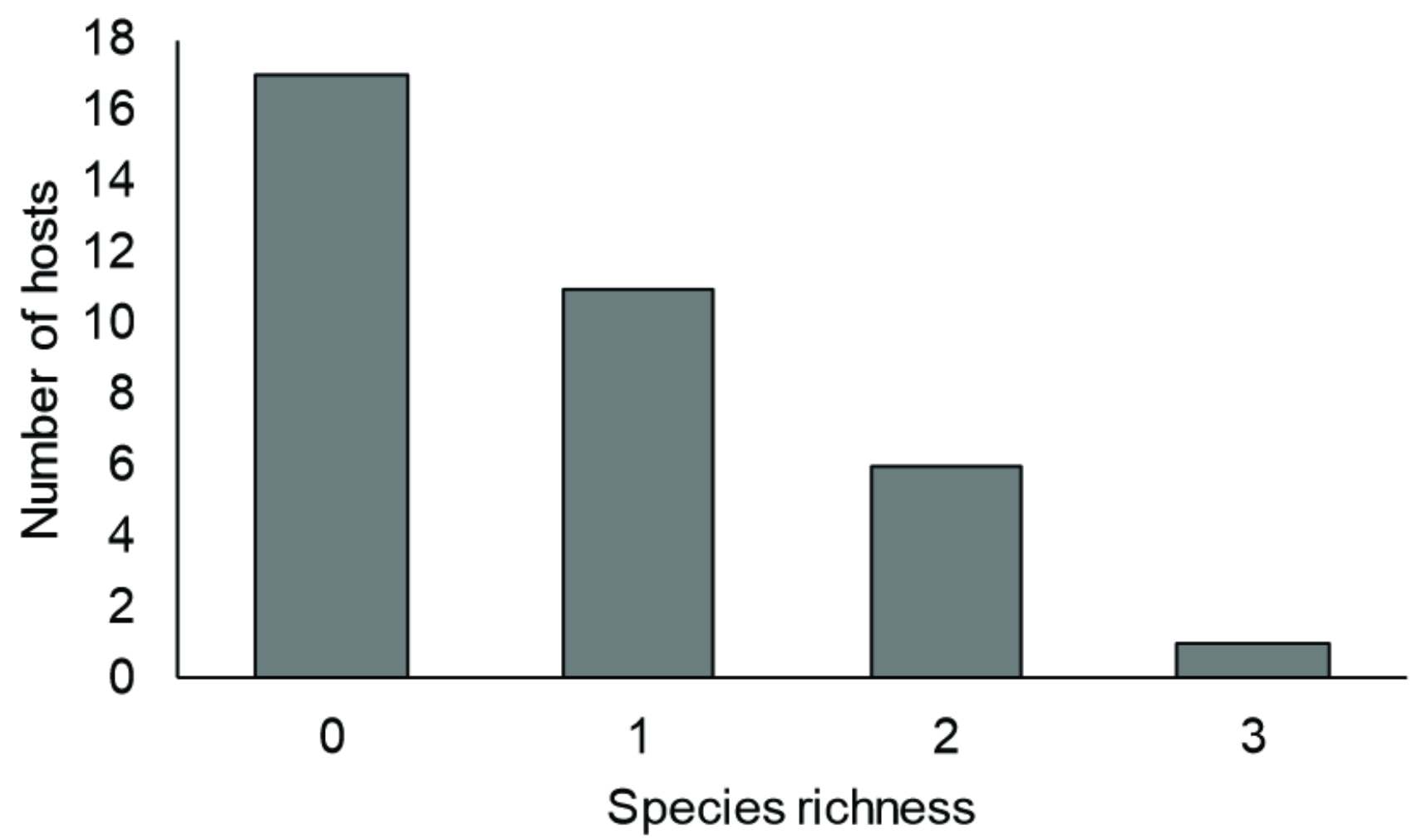

Figure 1

Species richness of ectoparasites in Mugil curema from the State of Amapá estuary (Brazil). 